\title{
Soft Tissue Sarcoma of the Head and Neck pT2 TNM Finding v8
}

National Cancer Institute

\section{Source}

National Cancer Institute. Soft Tissue Sarcoma of the Head and Neck pT 2 TNM Finding v8. NCI Thesaurus. Code C136666.

Soft tissue sarcoma of the head and neck with tumor measuring more than $2 \mathrm{~cm}$ but 4 $\mathrm{cm}$ or less in greatest dimension. (from AJCC 8th Ed.) 